\section{Terrorism and Right-Wing Extremism: History and Comparative Definitions}

\author{
Kwame Badu Antwi-Boasiako \\ Stephen F. Austin State University, USA \\ (iD) https://orcid.org/0000-0002-7469-3634 \\ Caleb Grant Hill \\ Stephen F. Austin State University, USA \\ https://orcid.org/0000-0002-0562-6737
}

Political Preferences

2020, vol. 26: 77-94

journals.us.edu.pl/index.php/PP

Submitted: 02/06/2020

Accepted: 21/06/2020

\begin{abstract}
:
Recent narratives on terrorism have focused on the definitions. Terrorism is not a new phenomenon, but the problem resides in its definition and who is defining it. Conceptualizing terrorism depends on which framework one utilizes. The use of different lenses to define the term has contributed to the lack of global acceptance of what constitutes terrorism, hence the difficulty of gathering data for analysis. It is also a conundrum when powerful nations legitimize their terrorist activities against weaker ones. This, unfortunately, has led to the subjectiveness of every attempt in the literature to objectively provide a globally acceptable definition. Using meta-analysis as the methodological approach for the study a number of definitions were scrutinised. This article provides a brief examination of the intersection between right-wing terrorism and ethnic nationalism, and how accelerationism escalates ideology into violence. The paper compares two acts of violence, one traditionally viewed as terrorism and the other labelled solely as a mass shooting. It concludes with a comparative analysis of the definitions provided, utilizing a case study to examine how labels of a terrorist or a freedom fighter impact on one's view of a group's motivation. This is pertinent when analysing ideologically motivated violence.
\end{abstract}

Keywords: terrorism, right-wing terrorism, ethnic nationalism, comparative analysis

\title{
Introduction
}

Since the genesis of recorded history, nations have been subjected to the destruction and violence associated with acts of terrorism. Operating in the name of defense or protecting their colonies and political ideologies, nations have used their militia and military power to engage in wellorchestrated atrocities (terrorism).Terrorism, arguably, has been seen as tactics used by weaker groups against stronger ones. While this argument may be true as established in the literature, this article maintains that terrorism is something that is done by both weak and strong parties (Antwi- 
Boasiako 2010: 104-106). Similarly, terror and terrorism are used interchangeably in this paper as both involve violence and fear (Dekmejian 2007; Holt 2005). Terrorism is seen as a sociopolitically constructed term with multiple definitions, which may originate from a variety of sources and directions given how one defines the term (Haahr-Escolano 2005: 70-71; Fine 2010). There are several types of terrorism in the academic literature, which include but are not limited to; civil disorder, political terrorism, non-political terrorism, quasi-terrorism, limited political terrorism, and state sponsored terrorism. This paper concerns itself primarily with political and state terrorism, as it examines the definitions of terrorism, and its contextual relationship within right-wing extremism and ethnic nationalism that seeks to utilize violence for separatist measures.

The paper traces the history of terrorism as an act and a concept. It tries to explicate the various definitions of terrorism and the conundrum of reaching international consensus on defining the term. Two important distinctions the paper will dwell on are the application of traditional terrorism frameworks and freedom fighter labels on certain violent acts. Therefore, the article will conduct a comparative analysis on two separate right-wing terroristic acts, noting similarities and differences based upon these distinct definitions. Ethnic nationalism, under the veneer of broad-based right-wing action, has the natural tendency to advocate for separatism due to desires for ethnic cleansing. While the momentum for right-wing separatists, arguably, is dying out, there exist pockets of individuals and groups that continue to advocate for separation ${ }^{1}$. Traditional terroristic definitions regard collective violence as inciting terror to separate, as the group is visible, and its goals are clearly defined compared to other terroristic instances from individuals or small militia groups. However, lone hate crimes, if viewed as terrorism, operate under the self-defined label of a criminal or a freedom fighter, not unlike a militant institution, as its desire in the terroristic act is not to solely incite violence but to symbolically separate from the pluralistic nation-state. Definitions, therefore, can be based upon the self-proclaimed status of the individual easier than through a group.

\section{Tracing Terrorism: The Early Beginnings}

The nature of terrorism has evolved since its fledging beginnings. That is, the origin of terrorism could be as old as when humans started employing violence against one another's behaviour. Scholars argue that modern terrorism began with the French Revolution (Erlenbusch 2015;

\footnotetext{
${ }^{1}$ For example separatist groups in Africa see: Sawe (2017).
} 
Shughart II 2006; Goldstone 1984) - a period of social and political upheaval from 1789 to 1799 and has been evolving ever since. We argue strongly that terrorism may be traced to the genesis of creation, and its shared causes, intent, or goals have never changed. Some of these common causes may include, but are not limited to land or territorial disputes, cultural differences, ideological differences, religion, Israeli-Palestinian conflict, political invasions, and sovereignty.

According to Fine (2010), in 70 AD, Josephus Flavius referred to a sect of Jewish zealots named the Sicarii who used assassinations as a tactic in the Jewish rebellion against Rome. Kaplan (2011: 104) maintains this was "the first recorded case of terrorism." The Sicarii, as Zeitlin (1965: 302) noted, were organized by Judas of Galilee who incited people to revolt against "tyranny of the Roman Empire financial enslavement." However, the Sicarii did not limit their aggression to the Roman State but extended their attack on those civilians who willingly submitted to the authority of Rome (Smith 1971). The Sicarii felt their acts against the Judeans were justified because they did not agree with their political aspirations. It was the Jews who first attempted to name the use of terror in a political context though it was the Assyrians who first developed the terminology for the use of political and military "means to inspire terror" (Fine 2010: 271).

While terrorism might be going on for political reasons and accomplishments in the eyes of victorious political leaders, this is perhaps the first instance where terror was seen as an evil act with negative connotation. However, during the French Revolution, the term "terrorism" had a positive connotation (Hoffman 2006). The concept of terror employed as a political idea was first utilized by the French Legislature in order to "suppress the aristocratic threat to the revolutionary government" (Bahan 2009: 336). The leader of the so-called "reign of terror", Robespierre, "stands apart as the first politician to organize and mobilize the resources of a modern nation to systematically eradicate his opponents" by dehumanizing them (Fine 2010: 278). Robespierre's regime de la terreur (reign of terror) shares at least two familiar characteristics with what may be described as the modern-day acts of terrorism. First the "reign of terror" (the use of the military) was well organized; second, its goal and justification were the creation of a "new and better" society in place of a fundamentally corrupt system (Hoffman 2006: 16). Differing from their successors, the leaders of the reign of terror typically shirked intentional military attacks against innocent civilians in order to maintain "political legitimacy" (Bahan 2009: 336). 


\section{The Indigenous and Terrorism}

Until the eve of the First World War (WWI), terrorism retained its positive revolutionary connotation. However, by the 1930s, terrorism was commonly used to describe the practice of mass repression in totalitarian states, used by dictatorial leaders against their own citizens. The practice became common in most African countries after gaining political independence from the evils of slavery and colonization (Hoffman 2006). Similarly, outside the continent of Africa, the author noted that Joseph Stalin (1879-1953) unleashed the "Great Terror" upon the then Soviet Union (the Union of Soviet Socialist Republics-USSR) and meant to "seize total power by terrorist action" (Hoffman 2006: 25). However, this connotation did not last much past WWII, after which the meaning of terror changed again. One of the biggest gaps in tracing the origin of terrorism and what constitutes terrorism is the focus on authoritarian and dictatorial regimes. But as it is evident in the literature, democratic countries also use their military to terrorise others. For example, Great Britain (treatment of the natives in the colonized; Africa and Australia), the USA (treatment of Native American Indians) (Matthews 2002) and the Portuguese in Brazil or Spain in South American countries (Fausto 1999). In the post-WWII era, those considered terrorists began targeting innocent civilians as means to "inspire media coverage and effect political change in targeted governments" (Bahan 2009: 337). It became the norm for violence to be actively used in nations not directly involved in conflicts in which innocent civilians were attacked for political and ideological reasons.

The concept of terrorism in a revolutionary context expanded in the 1960s and 1970s to include ethnic separatist groups, the disenfranchised, or exiled nationalist minorities. However, these groups often rejected the label "terrorists", preferring instead to be referred to as "liberators" or "freedom fighters" (Hoffman 2006). In the 1940s-1960s, individuals and groups in colonized African countries that began to fight for their political independence were not only seen as dangerous and terrorists but were also the targets of the colonizers (Anderson 2005; Elkins 2005). By the 1980s, terrorism evolved to new dimensions where, arguably, more frustrated, disfranchised, and marginalized individuals and groups rebelled against powerful authorities. Unfortunately, in what the literature describes as modern terrorism, it is not uncommon for individuals to act alone to cement their agenda through social media, or as a result of extensive global media coverage. While one may not be able to pinpoint the genesis of terrorism, its unfortunate violence and atrocities have escalated as a result of technological advancement in general. 


\section{Methodology and Data Collection}

According to Gerring (2012), there are several methods incorporating both observational data and quantitative approach, which were used to explain what researchers consider triangulation as this strategy is one of the potential solutions to a problem of conflicting tasks (the definitions of terrorism), and criteria to be identified in a multimethod research. So, what is triangulation? Babbie (2001: 113) defines triangulations as the "use of several different research methods," which he sees as "valuable research strategy". The terrorism data gathered from journal publications qualitatively were used to justify the definitions of terrorism through explanation.

Though the study used mixed methods approach not all methods were overly relied on, since there are some expected methodological disadvantages associated with every research method. However, meta-analysis was identified as more appropriate for this particular study. Meta-analysis, usually used in statistical methods for contrasting and combining results from different studies, is utilized in this article by examining the various definitions of terrorism. This article used secondary data by gathering information through publications on terrorism. First, classical definition of terrorism and terror as presented in the literature was examined while critical similarities and differences were discussed based on the literature. Meta-analysis, as a subset of systematic approach to case report, case control study, and cohort study, was used to examine various definitions in the literature. Admittedly, the sample of publications was very small, it was however determined that the definitions used represent or reflect the general definitions and understanding of terrorism, hence we found the definitions in other publications as repetitive and redundant. This determination was based on Internet search, which provided greater ability to generalize the definitions. Additionally, we used word (terrorism, terror, rightwing) Internet search to identify publications directly related to terrorism. We further narrowed the output of the Internet results by limiting our search to only peer reviewed journals, books, and authentic Internet sources.

\section{What is Terrorism? Who Defines it?}

Defining terrorism is a complicated task. Globally, there is no distinct internationally accepted definition of what really constitutes terrorism, and the terrorism literature abounds with contradicting and competing definitions and typologies. Additionally, it should be noted "that terrorism is not only the physical act of an attack but also the psychological impact it has on a 
society for many years after" (GTI 2019: 6). As Cronin (2005: 341) puts it, "terrorism is notoriously difficult to define, in part because the term has evolved and... it is associated with an activity that is designed to be subjective." Many studies argue that an "objective and internationally accepted definition of terrorism can never be agreed upon...since one man's terrorist is another man's freedom fighter" (Ganor 2002). The struggle in the search for a suitable globally acceptable definition seems impossible "because different bodies, organizations, and government agencies have different definitions to suit their own particular (political) role, purpose, or bias" (Bruce 2013: 26). Hunter (1991: 352) sees terrorism as "a political phenomenon aimed at achieving politically determined goals." For example, the slave and colonial masters did not see themselves as engaging in acts of terrorism. So, would the nations that engaged in slavery and colonization for centuries consider themselves as sponsors of terrorism? Affirming Bruce's submission, Carr (2007) argues there are no two agencies within the US government, for example, that have "identical" definitions. In most cases, agencies cannot reconcile on the definition of terrorism.

Terrorism is a complicated phenomenon, which requires a sophisticated strategy in achieving its goals. The League of Nations first attempted to define international terrorism in 1937 as a response to the assassination of the Yugoslavian Head of State, King Alexander I and "the President of the Council of the French Republic, Louis Bathou" (Bahan 2009: 344). Unfortunately, while the convention was adopted, it never came to fruition (Young 2006). Currently, there is a plethora of definitions of terrorism available in the literature, which tend to contradict each other.

\section{The Definition Conundrums}

There are several possible working definitions for terrorism. A terrorist is defined as "anyone who attempts to further his views by a system of coercive intimidation" (Hoffman 2006: 14). Gupta (2011: 99) defines terrorism as a political act by non-state actors, where participants, in contrast to common criminals, see their acts as a way of achieving public good, such as national independence, social justice, or "the establishment of a theocratic state, thus making them altruist in their own minds." Those who find this definition limiting may find more satisfaction in Ganor's (2002: 288) definition of terrorism as "the deliberate use, or threat, of violence against civilians in order to attain political, ideological, and religious aims." 
Those seeking a definition from sanctioned governmental agencies rather than academics might prefer the US Department of State's definition of terrorism contained in Title 22 of the United States Code Section $2656 \mathrm{f}$ (d). It defines terrorism as "premeditated, politically motivated violence perpetrated against other non-combatant targets by subnational groups or clandestine agents." The US Federal Bureau of Investigation (FBI), on the other hand, defines terrorism as "the unlawful use of violence against persons or property to intimidate or coerce government, the civilian population, or any segment thereof in furtherance of political or social objectives" (as cited by Hoffman 2006: 38). The US Department of Defence (DoD) takes a slightly different stance defining it as "the unlawful use of -or threatened use of- force or violence against individuals or property to coerce or intimidate governments or societies, often to achieve political, religious, or ideological objectives."

The United Nations (UN) has long struggled to settle on a definition of terrorism for global acceptance since its working definitions tend to accuse powerful nations of the very crime they claim to be fighting against. For years the UN avoided using the term "terrorism," even when specifically crafting policy to combat it, in order to avoid any political and ideological disputes surrounding the term (Saul 2005). In fact, the first time the UN actually used the term "terrorism" was in 1985 in the Security Council Resolution 579, which was crafted in response to "the excessive amount of global terror attacks". Additionally, the first time a direct link was made between terrorism and violations of human rights dates back to the 1993 Vienna World Conference on Human Rights (Symonides 2001). The UN avoided making any declarative statement regarding a definition of terrorism until October 2004, when it adopted the Security Council Resolution 1566, which generally, but not expressively, defines terrorism as:

...criminal acts, including against civilians, committed with the intent to cause death or serious bodily injury, or taking of hostages with the purpose to provoke a state of terror in the general public or in a group of person or particular person, intimidate a population or compel a government or an international organization to or to abstain from doing any act which constitute offences within the scope and as defined in the international conventions and protocols relating to terrorism (Saul 2005: 164).

At the International Convention for the suppression of financing terrorism, the UN once again made an indirect attempt to define terrorism as: 
Any other act intended to cause death or serious bodily injury to a civilian, or to any other person not taking an active part in the hostilities in situation or armed conflict, when the purpose of such act, by its nature or contest is to intimidate a population or compel a government or an international organization to do or abstain from doing an act (Bahan 2009: 346).

However, it could be argued that the UN's best effort to define terrorism occurred at the Draft Comprehensive Convention on Terrorism, which sought to label terrorism as a criminal offense if certain qualifications are met, describing a terrorist as:

Any person who commit an offence within the meaning of the present Convention if that person by any means unlawfully and unintentionally causes (a) Death or the serious bodily injury to any person; or (b) Serious damage to public or private property, including a place of public use, a State or government facility, a public transportation system, and infrastructure facility or to the environment; or $(c)$ Damage to property, places, facilities, or systems referred to in paragraph 1 (b) of the present article resulting or likely to result in major economic loss; when the purpose to conduct, by its nature or contest, is to intimidate a population, or to complete a Government or international organization to do or abstain from doing an $\operatorname{act}(361)$.

Given the above definitions, they are those that specifically mention targeting civilian populations which are most applicable to the argument concerning the differentiation between terrorists and freedom fighters. Here again, who decides which definition must be used?

\section{Terrorists or Freedom Fighters}

The Palestine Liberation Organization (PLO) Chairman, Yasser Arafat, including Nelson Mandela of South Africa, Muammar Al Gadhafi of Libya, who resisted foreign oppressive policies, especially, from the West were more often than not seen as terrorists ${ }^{2}$, but Arafat, for example, quibble rejected that label associated to him by Israel and the West claiming that "the difference between the revolutionary and the terrorist lies in the reason for which each fights"

\footnotetext{
${ }^{2}$ Those mentioned above were not the only ones considered or labelled as terrorists or supporting terrorism by the West. For example, even after 27 years of imprisonment and resisting apartheid rule in South Africa, the United States had the President of South Africa, Nelson Mandela, on its terrorist watch-list (Elliott 2019).
} 
(Hoffman 2006: 26). In fact, many groups that commit acts of terror eschew the pejorative terrorism label and prefer to think of themselves instead as freedom fighters or liberators. Nelson Mandela wanted equality for all in South Africa by rejecting the evils of apartheid in that country, while Kwame Nkrumah of Ghana and others wanted total liberation for Africans who were buried in the oppressive rule of European colonial governments.

These views strike many as a massive rationalization. Those who supported the contention of Arafat and his ilk could argue that they were merely freedom fighters; hence the distinction. The same argument could be made for, or against, some African leaders such as Robert Mugabe, Nelson Mandela, Jomo Kenyatta, Kwame Nkrumah, and others who led groups, such as the Mau Mau, to fight the evils of the British colonization and occupation for independence and freedom. Ganor (2002: 288) writes:

What is important in these definitions is the differentiation between the goals and the means used to achieve these goals. The aims of terrorism and guerrilla warfare may well be identical; but they are distinguished from each other by the means used-or more precisely, by the targets of their operations. The guerrilla fighter's targets are military ones, while the terrorist deliberately targets civilians. By this definition, a terrorist can no longer claim to be a "freedom fighter" because they are fighting for national liberation or some other worthy goal.

The systematic and continuous targeting of civilians is and should be the principle qualifier in any definition of terrorism. The difference between goals and the means by which the goals are achieved is a distinction that cannot be overstated. Terrorism is a tactic used to accomplish an objective, be it political, ideological, religion, or economical, but it is the indiscriminate targeting of civilians, which separated the modern-day terrorism from the Jacobin revolutionary.

The problem of the definition conundrum is that the terrorism literature is skewed as a result of dependence on data provided mostly by powerful nations (governments) and their agencies. So, if a government decides which criminal activities constitute or fit terrorism then the said government would label it so. It is not uncommon for powerful nations dropping bombs on civilians in the name of preventing the spread of communism or fighting terrorism, but those nations do not consider their actions as acts of terrorism. As Schmid and Jongman (2006: 180) lamented, "The perception of political terrorism as a practical problem requiring urgent solution 
has led to poorly defined, ideologically biased, conceptually skewed research." That is, "policyoriented research tends to impede sound theoretical work because of urgent social need (real or perceived) to achieve concrete results in the real world."

\section{Right Wing Terrorism as Ethnic Nationalism}

Political terrorism often manifests itself in the targeting of civilians because of personal, identifiable demographics. As noted by the Global Terrorism Index (GTI 2019: 4), in many parts of the West, there has been considerable growth in right-wing terrorist groups. This assertion is affirmed by the studies of the Institute for Economics and Peace (IEP), which states "far-right attacks in the West surge by 320 percent." Using data from 1970 to 2018, the study further avows "the last five years has seen an increase in far-right terror attacks in western countries" (GTI 2019). According to Heitmeyer (2005: 142):

Right-wing terrorism is a product of political interaction and the radicalization of other forms of threat-based right-wing attitudes and behaviour, such as opportunitydependent violence by (youth) gangs, subcultural violence (such as that of skinhead groups), organized party-political Right extremist violence, and religiously oriented right-wing extremist group violence.

Due to the decentralized nature of these groups, it is often difficult to define one group as right-wing. Often, self-identification descriptors - particularly race or religion - help determine the nature of a political terrorist group. In the West, most right-wing terrorists are self-described Christian, male, and white, and the connection to white nationalism has a low barrier of entry. Common psychological and sociological behaviour varies depending on the size of the group and the specific individual, though there is one common denominator: Right-wing extremist violence or terrorism is mostly carried out by a representative of the ethnic majority population against weaker minorities (Heitmeyer 2005: 144-145). Power is often exercised to suppress minorities over other demographics. However, regional differences can have a large impact on the political motivations of said group. In Europe, right wing violence has been propagated against foreigners, minorities, and the democratic institutions that pervade much of Western Europe and the developing Eastern Europe. One can contrast this with South America, where many of the right- 
wing groups have fought to stabilize current rulers and regimes, as they are in line with the political narrative extremists espouse.

Sprinzak (1995) has attempted a typification to help explain the many deviations within right-wing terrorism. It is historically based and includes a wide range of variants. These range of definitions and applications help to understand terroristic motivations and indicators better. They include revolutionary terrorism, reactive terrorism, vigilante terrorism, racist terrorism, millenarian terrorism, and youth counter-culture terrorism. However, there is room for discussion as to whether all the forms mentioned should be subsumed under the concept of "terror." For the sake of the previous definitions in this article, it is apt to include these generalized forms as adequate for understanding violence against civilians to induce or incite terror. One of the primary forms of right-wing extremism is reactive in nature, as many xenophobic narratives react to changing demographics and attempt to dissuade this change through overwhelming others with fear and often violence.

Bridging the gap between general right-wing thought and reactionary nationalism can create terrorism that breeds separatist organizations. The primary vehicle for this shift is through escalation. "Escalation depends on the political interaction processes which include three essential elements: the socialization of the perpetrators, the organization of the groups and their ideology, and the opportunity structure" (Heitmeyer 2005: 146). As singular right-wing individuals with fringe political ideas are escalated through nationalistic socialization, groupthink has the potential to overpower individuals and indoctrinate them into ethnic nationalism. When indoctrinated, the group grows and authorizes the potential for future violent tendencies as an ideological feedback loop justifies the "us vs. them" mentality. This leads toward "accelerationism", a fringe philosophy that promotes mass violence to fuel society's collapse (Kunzelman 2020). When opportunity presents itself, it becomes as no surprise that a group focused on exerting power takes the chance, often in violent tendencies, irrespective of who it damages. The objective is to fashion a separate society with a worldview similar to their own, and due to the zero-sum nature of radical political ideology, nationalist extremists only have one way to adopt their personal policy. Reinares (2005: 126) writes a potential separate account of escalation from right-wing to nationalist terrorism:

More typically, though, terrorism is adopted by weakened nationalist separatist organizations as a tactical innovation in their repertoire of disruptive collective 
action. These political organizations may prove unable to reach influential stances through conventional procedures, see themselves affected by time constraints in order to benefit from changing opportunity structures or have been expelled from relevant public decision-making processes, in this last case, either as a result of state coercion or simply open pluralistic competition, electoral processes for instance.

The comparative analysis following this section examines escalation and opportunity from two perspectives, the Irish Republican Army and a mass shooting motivated by white nationalism, and deconstructs them with the previous definitions of terrorism; put simply, how can these cases be viewed through the lens of a traditional terrorist act or as a non-traditional freedom fighter advancing their liberation narrative?

\section{The Role of Institutions: Irish Republican Army}

The Irish Republican Army (IRA) was originally formed in 1919 to halt British rule in Northern Ireland using armed force. It fought for a unified Republic of Ireland through independence. In 1969, there was a resurgence of nationalistic feelings, but the group split into two camps: Officials and Provisionals. Officials sought separation via peace, but the Provisionals waged an increasingly violent campaign against the British Army for nearly 30 years and knew only violence (Cowell-Meyers \& Arthur 2010). Overall, an estimated 1,800 people were killed due to the Provisional IRA's actions, and many of these were civilians. White (1993) writes about the escalation process that divided the two camps:

Protestant vigilante violence that met the basically Catholic civil rights movement in Northern Ireland during the late 1960s, as well as unexpected repression by the British armed forces and security agencies since the early 1970s, prompted the Provisional IRA to terrorist retaliation and produced a transfer of legitimacy among the affected population.

The Provisional IRA was driven largely by frustration due to Catholic discrimination by a Protestant government and population, opportunity due to civil rights violations, and perceived inability to achieve their goals by the peace seeking Official IRA (The Irish Times 2003). Units of the Provisional IRA were organized to defend Catholic communities and were sustained by support from other units in Irelands. In 1969, the IRA formally divided along these faction lines. 
Violence by extremists against the Catholic civil rights demonstrators, unhindered by the mostly Protestant police, set in motion a series of escalating attacks (Cowell-Meyers \& Arthur 2010). This manifested itself into an institution with goals for separation - perhaps not solely independence and reunification - that sought to incite terror in a separate ethnicity and religious demographic.

Of all their actions, one of the most notable was the bombing of Belfast, UK on July 21, 1972, known as Bloody Friday. This event was the peak of the most critical and dangerous year of the North Ireland "Troubles". On Bloody Friday, the IRA exploded 26 bombs across Belfast in the span of eight minutes. Most of them were car bombs designed to target transportation infrastructure. Nine people were killed: five civilians, two British soldiers, a reservist, a political official, and 130 were injured (The Irish Times 2003). This event has traditionally been viewed as a terrorist attack. As the literature has noted, the murder of civilians in an attempt to attain political aims is promptly considered terrorism (Ganor 2002). The IRA's primary goal was to inflict pain upon a populace they disagreed with ideologically, to the point that violence was the only measure to seek resolution for their political disagreement. Operating under a terroristic definition, violence should not be condoned against civilians. A group that comes in to change the status quo by force is not exercising civil disobedience. As an institution, there is the potential for this insurgency to gain legitimacy, but that does not dissuade their agenda as terroristic (Reinares 2015; Heitmeyer 2015). So long as their actions terrorize non-combatants, they are a terroristic group, irrespective of affiliation and the war they seem to be fighting. Their group status does not legitimize their actions. However, the question arises that the IRA engaged in acts of warfare with combatants. While this perhaps wrestles out of the previous definition, revolutionary terrorism often requires clashing against the military institution. In this case, it is proper to separate operations to inflict damage upon non-combatants from those committed against combatants, as the terrorism definition is different. Thus, the IRA, as many terroristic institutions do, operates under two working definitions.

Juxtaposed with this framework is the IRA's view of their actions. As a right-wing separatist organization, the civil rights violations per the Protestant police force has prompted violence as a means to enact change (The Irish Times 2003). However, the change they wish requires restructuring of the current status quo: One ethnic, religious group overseeing another. Therefore, anyone who operates inside this system helps propagate it through sheer apathy. 
Civilians are not innocent, and if they are unwilling to follow in this liberation, they must be liberated through violence. The members of the IRA considered themselves freedom fighters thus fighting to free their homeland from the imposed crown in exchange for true freedom. They were revolutionaries, and altruistic in their aspirations. This desire for autonomy to rule superseded traditional human rights considerations, as the system propped up human rights violations through sheer indifference in the populace. Under this framework, they are not terrorists, regardless of the terror they create or how one defines terrorism. Their motivation is to forcefully unshackle the Irish, Catholic ethnicity from an imposed British and Protestant monarchy. If they had been the victor, perhaps a unified - or at least separated - Catholic Ireland would view them as their saviour.

\section{Understanding Lone Wolf Terrorist as a Freedom Fighter for the Ethnic State}

Contrasted with traditional views on terrorism, lone wolf terrorism is often perceived based upon the committed act rather than the motivation or emotion incited. Individuals who commit mass murder are labelled as murderers, committing hate crimes and not revolutionaries or terrorists, and this is especially true within right-wing extremist circles. One of the recent incidents that straddles the line between being labelled right-wing terrorism or simply mass murder is the 2019 Walmart shooting at El Paso, Texas. On August 3, 2019, Patrick Crusius, a 21-year-old white man, opened fire at a shopping center in El Paso. He killed 20 people and injured 26 others (Romero et al. 2019). Crusius was arrested and subsequently charged with capital murder. Police believe that a manifesto with white nationalist and anti-immigrant themes, which cited the year's earlier Christchurch mosque shootings and the right-wing "Great Replacement" conspiracy theory, was an inspiration for the attack (BBC News 2019). While the Federal Bureau of Investigation (FBI) investigation saw the shooting as an act of domestic terrorism, previous literature has noted the uncertainty by which legal articles within the FBI define terrorism. Therefore, this mass shooting provides a perfect case by which to compare and contrast two competing definitions: whether this is right-wing terrorism, or, per the Great Replacement motivation, a freedom fighter desiring ethnic liberation.

While it is not far-fetched to consider a mass shooting as terrorism, the next logical step is to claim this shooting as domestic terrorism. However, due to federal legal definitions and the desire to label criminals based upon their crime, not their motivation, there are societal 
hesitancies that make it unlikely and very difficult to define an individual as a terrorist (Bouhana et al. 2018). Lone-actor terrorism is not unique to either extremist ideology, yet its emergence in the 20th and 21st centuries is strongly tied to developments in right-wing extremism (Bouhana et al. 2018: 150; Ross \& Gurr 2007). As this overwhelming lone-actor terrorism is politically charged, those who subscribe to right-wing political thought, keeping in mind their similar, though not as extreme, politics, do not find it prudent to label one form of violence as different. Yet this concern is overturned by the prevailing definition of terrorism, as a mass shooter often targets civilians to murder and incite fear in the populace. Unless opportunity or necessity presents itself, a mass shooter does not engage in armed forces. Therefore, this case is easier to be labelled under one definition of terrorism rather than the many competing ones noted earlier.

However, interpretation of violent acts is in the eye of the beholder, the definer. Perhaps it is anathema to consider a mass shooter as a freedom fighter, but due to the political motivation of Crusius's attack, there is the potential to consider his shooting as an opportunity to liberate his fellow white nationalists. His appeal to the Great Replacement theory helps frame such a narrative (Romero et al. 2019). The Great Replacement theory is a white nationalist far-right conspiracy theory which argues that, with the complicity or cooperation of "replacist" elites, the white European population is being progressively replaced with non-European peoples (Bowles 2019). This theory is included in a larger white genocide conspiracy theory that has spread in Western far-right movements since the late 20th century. As a freedom fighter, Crusius is fighting to overthrow the liberal elites who wish to replace his ethnicity with other, more diverse, ethnicities. To him, the Latino population in America is invading his country, his land, and his very way of life. With the connection to identity so grounded in his political ideology, the potential for violence increased to the point where removing the problem through means of force was the only solution. Lone wolf far-right extremists are often antisocial, where their need to hurt others manifests itself through a crisis (Bouhana et al. 2018: 154-155). Crusius's crisis, while a self-delusional conspiracy, was based on the very bedrock of his identity. Stripped of his identity, all he had was the potential for freedom, and he capitalized on this opportunity. As demographics continue to shift, possibilities for fractured right-wing cells to emerge will remain persistent. The prevailing question is, if one individual's motivation is far enough left to shift the Overton Window, will their actions be considered per their motivation or the aftermath? 


\section{Conclusion}

Terrorism has always been a complicated issue and almost impossible to define given its relativity. Since the first cases of documented terrorism committed by the Sicarii to the attacks on the US on 9/11 and thereafter, the definition of terrorism has fluctuated with the times, while the violence as a common denominator remains constant. Those are our individualistic or societal perceptions of terror that have proven the most difficult challenge to producing a universally accepted definition of terrorism. Bahan (2009) argues, "in order for international terrorism to be universally defined, the international community must be sensitive to the diverging specific normative values of different states" and actors. However, if we may, as Ganor (2002) suggests, create an objective definition that is based on accepted international law and principles concerning behaviours that are permitted among nations in conventional wars; and then further distinguish the non-state actors that deliberately use violence or the threat of violence to attain political, religious, and ideological objectives, then we may differentiate between "means used to achieve these goals."

If one furthers the definition that terrorism is the murder of innocent civilians, then the umbrella term is broadened. Even freedom fighters, in their bid to pursue an ideal society, sometimes attack civilians who cling to the status quo and stand in their way, however indirectly. Right-wing extremism, especially when escalated into ethnic nationalism, straddles the line between these two competing definitions. Their desires are inherently political, based on a perceived injustice by the other side, the left-wing political spectrum. Therefore, it should come as no surprise that the means to advancing their political belief system utilizes force, often directly and indiscriminately. When a right-wing extremist terrorizes a mall, the problem in defining the action lies in the motivation for the attack, the number of people involved in propagating the violence, and how one labels the criminal. Merely calling the person a criminal, over a terrorist or a freedom fighter, lends credibility to their actions, as a crime is only an act breaking a law instituted by the status quo. It is imperative, when comparing competing definitions of terrorism, that the cause be included in the analysis, not solely the effect. It is here that this delineation has issues, as the case studies have shown, but it is a generalized, workable operational framework. 


\section{References:}

Anderson, D. 2005. Histories of the hanged: The dirty war in Kenya and the end of empire. New York, NY: W.W. Norton \& Company.

Antwi-Boasiako, K. B. (2010). Defining international terrorism: Historical reality and the African experience. Journal of Comparative Politics, 3(2), 104-24.

Babbie, E. (2001). The Practice of Social Research. $9^{\text {th }}$ Ed. Belmont: Wadsworth Thomson.

Bahan, C.A. (2009). International terrorism: The legitimization of safe harbor states in international law. New York Law School Law Review, 54, 333-68.

BBC News. (2019). Texas Walmart shooting: El Paso attack domestic terrorism. BBC News. https://www.bbc.com/news/world-us-canada-49226573 (04/04/2020).

Bouhana, N., Corner, E., Gill, P,. \& Schuurman, B. (2018). Background and preparatory behaviours of right-wing extremist lone actors: a comparative study. Perspectives on Terrorism, 12(6), 150-63.

Bowles, N. (2019). 'Replacement theory,' a racist, sexist doctrine, spreads in far-right circles. The New York Times. https://www.nytimes.com/2019/03/18/technology/replacement-theory.html (27/03/2020).

Bruce, G. (2013). Definition of terrorism: Social and political effects. Journal of Military and Veterans Health, 21(2), 26-30.

Carr, C. (2007). Terrorism: Why the definition must be broad. World Policy Journal, 24(1), 47-50.

Cowell-Meyers, K. \& Arthur, P. (2010). Irish Republican Army. In Encyclopaedia Britannica Online. https://www.britannica.com/topic/Irish-Republican-Army (20/05/2020).

Cronin, A. (2005). "Behind the curve: Globalization and international terrorism." In: Readings in World Politics: A New Era. Edited by S. L. Spiegel, J. Morrions, F. L. Wehling \& P. Williams (pp. 340-59). United States: Thomson and Wadsworth.

Dekmejian, H. R. (2007). Spectrum of terror. Washington, DC: CQ Press.

Erlenbusch, V. (2015) Terrorism and revolutionary violence: The emergence of terrorism in the French Revolution. Critical Studies on Terrorism, 8(2), 193-210.

Elkins, C. (2005). Imperial reckoning: The untold story of Britain's gulag in Kenya. New York: Henry Holt and Company.

Elliott, J. K. (2019). Why anti-apartheid hero Nelson Mandela was once labelled a terrorist. GlobalNews. https://globalnews.ca/news/5201623/nelson-mandela-apartheid-terrorist-south-africa/ (10/05/2020).

Fausto, B. (1999). A concise history of Brazil. New York, NY: Cambridge University Press.

Fine, J. (2010). Political and philological origins of the term "terrorism" from the ancient near east to our times. Middle Eastern Studies, 46(2), 271-88.

Ganor, B. (2002). Defining terrorism: Is one man's terrorist another man's freedom fighter?. Police Practice and Research.3(4), 287-304.

Gerring, J. (2012). Social science methodology: a unified framework. Cambridge: Cambridge University Press.

Goldstone, J. A. (1984). Reinterpreting the French Revolution. Theory and Society, 13(5), 697-713.

GTI (2019). Global Terrorism Index 2019: Measuring the Impact of Terrorism. Sydney: Institute for Economics \& Peace.

Gupta, D.K. (2011). Terrorism, history, and historians: A view from a social scientist. Journal of American History, 98(1), 95-100.

Haahr-Escolano, K. (2005). "Iran's changing relationship with Hezbollah.” In Unmasking Terror: A Global Review of Terrorist Activities. Edited by Ch. Heffelfinger (pp. 69-72). Washington,DC: The Jamestown Foundation. 
Heitmeyer, W. (2015). Right-wing terrorism. In: Root Causes of Terrorism: Myths, reality and ways forward. Edited by T. Bjørgo (pp. 141-53). Abingdon: Routledge.

Hoffman, B. (2006). Inside terrorism. New York, NY: Colombia University Press.

Holt, A. (2005). South Africa in the war on terror. In: Unmasking Terror: A Global Review of Terrorist Activities. Edited by Ch. Heffelfinger (pp. 92-96).Washington, DC: The Jamestown Foundation.

Hunter, S. T. (1991).Terrorism: A balance sheet. In: At Issues Politics in the World Arena (6 ${ }^{\text {th }}$ ed). Edited by S. L. Spiegel (pp. 350-65). New York: St. Martin's Press.

Kaplan, J. (2011). History and terrorism. Journal of American History, 98(1), 101-105.

Kunzelman, M. (2020). Report: surge in white nationalism ramps up violence threat. ABC News. https://abcnews.go.com/US/wireStory/report-surge-white-nationalism-ramps-violence-threat-69664607

$(20 / 05 / 2020)$.

Matthews, E. G. (2002). E pluribus unum: Justice, liberty, and terror: An analysis of Western terrorism on people of African descent in the diaspora. Mason, $\mathrm{OH}$ : Thomson Custom Publishing.

Reinares, F. (2015). Nationalist separatism and terrorism in comparative perspective. In Root Causes of Terrorism: Myths, Reality and ways Forward. Edited by T. Bjørgo (pp. 119-30). Abingdon: Routledge.

Romero, S., Fernandez, M., \& Padilla, M. (2019). Day at a shopping center in Texas turns deadly. The New York Times. https://www.nytimes.com/2019/08/03/us/el-paso-walmart-shooting.html (20/05/2020).

Ross, J., \& Gurr, T. (2007). Why terrorism subsides: a comparative study of Canada and the United States. Comparative Politics, 21(4), 405-26.

Saul, B. (2005). Definition of 'terrorism' in the UN Security Council: 1985-2004. Chinese Journal of International Law, 4(1), 141-66.

Sawe, B. E. (2017). 10 Separatist Movements in Africa. WorldAtlas. https://www.worldatlas.com/articles/10separatist-movements-from-africa.html (02/04/2020).

Schmid, A. P., \& Jongman, A. J. (2006). Political terrorism. London: Transactional Publishers.

Shughart II, W. F. (2006). An analytical history of terrorism, 1945-2000. Public.Choice, 1(28), 7-39.

Smith, M. (1971). Zealots and Sicarii: Their origins and relation. The Harvard Theological Review, 64(1), 1-19.

Sprinzak, E. (1995). Right-wing terrorism in a comparative perspective: The case of split delegitimization. In Root Causes of Terrorism: Myths, Reality and ways Forward. Edited by T. Bjørgo (pp. 17-43). Abingdon: Routledge..

Symonides, J. Z. (2001). International law and the struggle against terrorism. The Polish Quarterly of International Affairs, 10(4), 22-39.

The Irish Times (2003). That dreadful year of 1972. The Irish Times. https://www.irishtimes.com/opinion/thatdreadful-year-of-1972-1.344116 (01/06/2020).

White, R. (1993). Provisional Irish Republicans: An oral and interpretive history. Westport, CO: Greenwood Press.

Young, R. (2006). Defining terrorism: The evolution of terrorism as a legal concept in international law and its influence on definitions in domestic legislation. BC International and Comparative Law Review, 23(1), 23-105.

Zeitlin, S. (1965). Masada and the Sicarii. The Jewish Quarterly Review, 55, 299-317. 